\title{
Policy Evaluation of Waste Water Treatment Plant (WWTP) Program in Laweyan Batik Village, Surakarta in Order Establishing Sustainable Development
}

\author{
E Asrida \\ Airlangga University, Surabaya \\ enny.asrida-2018@,fisip.unair.ac.id
}

\begin{abstract}
Surakarta is a city of culture, can be seen in terms of physical and non-physical, especially by maintaining traditional elements and values. The city of Surakarta in recent years has become increasingly known in the world of tourism by introducing batik as an icon of the city of Surakarta. Therefore, many tourists both from domestic and abroad make the city of Surakarta as a tourist destination, especially batik. The city of Surakarta is also known as one of the batik producers in Indonesia. In the city of Surakarta there is a batik village that was made an icon as a place for making and selling batik, namely Laweyan Batik Village. As an industrial center, Laweyan Batik Village has become a tourist destination for tourists. Batik is one of the industries that contributes considerable liquid waste, especially in terms of coloring or dyeing. Because of that, the Surakarta City Government took the initiative to create a WWTP program in Laweyan Batik Village. The research method uses descriptive qualitative. In the case of WWTP management, collaboration between the Surakarta City Government and batik craftsman using WWTP is needed, namely small and medium industries. The WWTP program is very helpful for batik craftsman in Laweyan Batik Village and good governance is needed to protect the environment around Laweyan Batik Village in order to keep clean the environment and health in order to achieve sustainable development.
\end{abstract}

Keywords: Policy Evaluation, WWTP Program, Sustainable Development.

\section{INTRODUCTION}

Talking about culture, who does not know the diversity of the Indonesian nation. Various kinds consist of the Indonesian nation and thousands of tribes spread throughout Indonesia. The various tribes in Indonesia created a culture that is characteristic of an area. Lots of culture is the result of a person creativity, taste, and intention to form an identity that will be remembered by the next generation. In the 21 st century is known that in the economic structure of the country Indonesia experienced many changes, especially the transformation from the agricultural sector to the industrial sector. Main priority development in the industrial sector is included in the National Development Plan in order to improve the welfare of the community and as an addition to the country foreign exchange. Therefore, the industrial sector is a mainstay, especially the textile and textile products (TPT) industries. Batik is one of the products of TPT (small industry and textile products). Batik is an authentic traditional product and has become an Indonesian 
icon abroad. Batik is a cultural heritage that we need to protect and preserve. Laweyan Batik Village is one of the famous icons in Indonesia. As a place for batik artisans, contributes to environmental pollution, especially from batik waste resulting from dyeing or coloring. Batik waste comes from small or medium industrial batik artisans. In this case, The City Government of Surakarta took the initiative to make WWTP in collaboration with batik craftsman.

The WWTP (Waste Water Treatment Plant) Program is a decentralized waste water treatment system. WWTP Technology was developed by the Surakarta Rural Technology Development Institute (LPTP), tested for community-based organic waste water and sanitation treatment. WWTP technology is widely applied as livestock waste treatment, food processing industry, domestic waste (household), hospital and hotel waste. The WWTP Program is regulated in a Regional Regulation No. 2 of 2006 concerning Environmental Control.

Environmental problems have become a hot topic lately, mostly found in water sources, such as surface water and ground water which are carried out from various human activities. The sources of water pollution come from the daily activities of humans, industry and agriculture. Waste generated from various kinds of human activities can be in the form of domestic waste, industrial waste, and agricultural waste. Domestic waste comes from a variety of household activities. Environmental problems can occur due to climate change, the presence of extinct species, a prolonged dry season so that difficulties in finding food and increasing the volume of waste. Domestic waste such as detergents from washing activities carried out by people who live on the banks of the river, garbage from households is also disposed of directly into water bodies, and human waste. Every country has an integrated liquid waste management system that minimizes its environmental impact. Whereas industrial waste can come from small to large scale industries, such as tofu making industry, leather tanning, pulp, textile (batik).

The problem of environmental pollution from industrial waste is caused by the remnants of the process of the batik-making industry. Many batik (small and medium industries) in Surakarta City are not good in treating the rest of the waste disposal process. One example is the industrial area of Laweyan Batik Village. Which is also a tourist area. In this area, there is a place of batik production which has been a business that has been going on for decades in carrying out various types of batik in the region which is still thick with traditional atmosphere. Laweyan Batik Village is still one of the areas that is being increased in potential, both in terms of economy and tourism. An increase in waste in developing countries has an impact on urban infrastructure. In dealing with crises such as clean water, environmental pollution, increased waste, it is all due to the industrialization that is not well managed.

The development of the center of the batik area in the Laweyan area is inseparable from the small home-based businesses of the local population, but unfortunate that the processing of industrial waste has not been regulated like a large industry which requires processing of residual production waste, in this case liquid waste. Environmental problems have been a critical issue for governments worldwide, as both developed and emerging countries are facing severe pollution disposal and resources conservation problems caused by industrialization, growing population, and limited resources, among others. Disposing of industrial waste that is not environmentally friendly will disrupt ecosystems in the environment, resulting in environmental pollution to disrupt the life chain of the ecosystem. Littering can have an environmental impact. The laweyan batik area is an area where the Jenes River is crossed, which is due to the activities of the batik-making process, so that the remnants or liquid waste from the batik-making process are flowed into the river so that it impacts the environmental pollution of the river. To prevent water pollution from waste water, collaboration is needed between the community, relevant agencies, and the city of Surakarta. The problem of environmental pollution, water pollution causes a variety of negative impacts that are now very pronounced, especially in urban areas. 
One of the problems is the scarcity of clean water which will also have an impact on public health as users of water. Therefore, to minimize water pollution caused by the disposal of liquid waste into water sources, it is necessary to treat waste water before it is discharged to these water sources. Small and medium industries can use simple waste water treatment systems. Large industries must have their own waste water treatment plants that meet the requirements. After going through the treatment process, if the liquid waste can still be utilized, then the waste can be recycled or reused. Waste that cannot be reused before being discharged into water bodies must meet the liquid waste quality standards. Liquid waste quality standard is a limit on the level and amount of pollutant elements that can be tolerated in liquid waste from a certain type of activity to be disposed. In order to achieve sustainable development, there needs to be a key element, namely the availability of clean water. Environmental problems are problems that have always been a problem throughout the world such as in developed or developing countries, especially the problem of waste disposal caused by industrialization. In waste disposal, it is necessary to formulate a policy in waste management and consistency. To realize the optimal batik waste water treatment program and sustainable actions are needed and empowerment for batik craftsman as an effort to realize good governance within the framework of sustainable development.

\section{RESEARCH METHOD}

\subsection{Theoretical Framework}

Policy is an alternative set that has been chosen based on certain principles. Policy is the result of in-depth analysis as an alternative that leads to decisions about the best alternative. Public policy is a strategic use of available resources to solve public or government problems. Then, public policy is a series in which interconnected choices are made by government agencies or officials in fields related to governmental tasks, such as defense, security, energy, health, education, community welfare, crime, urban areas and others. Policy is anything that the government chooses to do or not to do.

\subsection{Policy Evaluation}

Policy evaluation is a learning about the consequences of a public policy.

\subsection{Policy Evaluation Criteria}

In assessing the success of a policy needs to be done through several indicators of policy evaluation. A policy that has been implemented must produce information about policy performance. Some criteria in assessing policy performance as follows:

Tabel 1. Evaluation Criteria Table

\begin{tabular}{lll}
\hline Criteria Type & Question & Illustration \\
\hline Effectiveness & $\begin{array}{l}\text { Whether the results are } \\
\text { desired has been achieved? }\end{array}$ & \\
\hline Efficiency & $\begin{array}{l}\text { How much effort is needed } \\
\text { to achieve the desired }\end{array}$ & Net bent \\
& results? & Benefit cost ratio \\
\hline
\end{tabular}




\begin{tabular}{lll}
\hline Adequacy & $\begin{array}{l}\text { How far has the desired } \\
\text { outcome been solved the } \\
\text { problem? }\end{array}$ & $\begin{array}{l}\text { Fixed costs (type I problems) } \\
\text { Fixed effectiveness (type II } \\
\text { problems) }\end{array}$ \\
\hline Equity & $\begin{array}{l}\text { Are costs and benefits } \\
\text { distributed by evenly on oreto Criteria } \\
\text { groups that different? }\end{array}$ & $\begin{array}{l}\text { Caldor-hicks Criteria } \\
\text { Rawls Criteria }\end{array}$ \\
\hline Responsiveness & $\begin{array}{l}\text { Does the policy result } \\
\text { satisfy the needs, onsistency with the survey } \\
\text { preferences or values of } \\
\text { certain groups? }\end{array}$ \\
\hline Accuracy & $\begin{array}{l}\text { Are the desired results Public programs must be } \\
\text { (goals) really useful or equitable and efficient } \\
\text { valuable? }\end{array}$ \\
\hline
\end{tabular}

\subsection{Waste Water Treatment Plant (WWTP) Program}

Liquid waste is a liquid that comes from the rest of the process and other business activities that are not reused. Efforts are needed to overcome environmental pollution, especially water consisting of waste treatment and can recycle waste. Before liquid waste is discharged into water bodies, it must be treated first. The main purpose of waste treatment is to eliminate or reduce the hazardous nature of liquid waste, especially batik waste, in this case it is useful to reduce the spread of diseases caused by pathogenic organisms in the waste, so that effluent water will not endanger human health, especially people who live near waste disposal sites. Furthermore, efforts should be made to prevent pollution and environmental damage.

The WWTP (Waste Water Treatment Plant) Program especially in Laweyan Batik Village has become a spotlight and a hot topic among the wider community, both those came from the people of Surakarta City and people from various regions, especially from batik village outside the area, due to the WWTP being a model for batik village in other areas. So, in the future is expected that the use of the WWTP can be reviewed for the utilization of the WWTP program, so that it can be increased or the WWTP procurement can be added again.

\subsection{Policy Evaluation of WWTP (Wastewater Treatment Plant) Program in Laweyan Batik Village Surakarta}

Evaluation is an activity to assess the level of performance of a policy. An evaluation can only be done if a policy has been running for quite some time. There is no definite time limit for when a policy must be evaluated. The indicators used are Effectiveness, Efficiency, Adequacy, Equity, Responsiveness, Accuracy.

Evaluating a program or public policy requires criteria to measure the success of the program or public policy. In this case, the performance of policies that produce information there are criteria in evaluating where these criteria are used as indicators of research in evaluating the WWTP Program in Laweyan Batik Village Surakarta.

\subsection{Method and Type Research}

In order to evaluate the policy in the utilization of the wastewater treatment plant (WWTP) program in Laweyan Batik Village, Surakarta in order establishing sustainable development, this research uses descriptive qualitative research methods. The type of 
descriptive research provides a detailed and very accurate picture, as well as finding new data that conflicts with old data, creating a series of categories or classifying types, explaining a series of stages or steps, documenting the process or mechanism of causation, reporting background or context of the situation.

This type of research is a qualitative descriptive study. This descriptive research is intended for careful measurement of certain social phenomena. The approach taken in this study is a qualitative approach that is presented in the description. In qualitative research that focuses on descriptive offerings, the data collected is mainly in the form of words, sentences or images that have meaning rather than just frequency. Researchers emphasize notes that describe the actual situation to support the presentation of data. By using descriptive qualitative research methods, researchers can obtain credible and meaningful data.

\subsection{Research Sites}

The location of this research conducted in Laweyan Batik Village, Surakarta City with the consideration that the Laweyan district is the center of the batik industry. So, it needs to be researched to overcome the problem of water pollution in the form of batik liquid waste, especially those originating from the batik industry center area using the WWTP program.

\section{RESULTS AND DISCUSSION}

The City Government of Surakarta in this case through the Department of the Environment seeks to overcome water pollution from batik waste that occurs in Laweyan Batik Village is by holding an environmental control program, especially liquid waste. Efforts made through the WWTP (Waste Water Treatment Plant) Program. WWTP is a decentralized waste water treatment system consisting of treatment modules that are appropriate to the application as well as easy dissemination in maintenance and operation. Evaluation is an activity to assess the level of performance of a policy. A new evaluation can be carried out if a policy has been running in sufficient time. There is no definite time limit, when a policy must be evaluated. In this discussion will be discussed namely: Effectiveness, Efficiency, Adequacy, Equity, Responsiveness, Accuracy.

\subsection{Effectiveness}

If the achievement of organizational goals is very good, the effectiveness is a greater. The achievement of goals greater than the organization, the results to be achieved from these goals. After the implementation of public policy activities, the impact was not able to solve the problems faced by the community, it can be said that a policy activity was declared a failure, but after going through a certain process a public policy results were not immediately effective in the short term. The effectiveness has been classified as good, because of the presence of WWTP facilities residents do not dispose of batik waste carelessly again, so that the surrounding community can live healthier and cleaner. We need the support or contribution from the Surakarta City Government to be more concerned in overcoming the problem of batik waste.

\subsection{Efficiency}

Efficiency is something that uses our resources optimally to achieve a certain goal. Efficiency will be realized if the use of resources is optimally empowered so that a goal will be 
achieved. Efficiency refers to the amount of effort needed to produce a certain level of effectiveness. Efficiency is related to effectiveness and effort, generally measured by monetary costs. If the target to be achieved is a public policy it turns out to be very simple while the costs incurred through the policy process are too large compared to the results achieved. This means that the policy activities have been wasteful and not feasible to be carried out.

A program can be said to be efficient if in carrying out something pay attention to the accuracy of the way both business, work, do not waste time, effort and cost. The program has been running quite well, it is just that in terms of the costs of post-WWTP manufacturing there are costs for the maintenance of the WWTP. So that the community objected to being charged for the care and maintenance. Even though this is very important, if the WWTP program is specifically designed to empower the community and place the community as the actor, decision maker and person in charge of all activities. The WWTP program requires the involvement of the community in meeting their own needs.

\subsection{Adequacy}

The adequacy of the waste water treatment plant program in the Laweyan Batik Village, Surakarta in order establishing sustainable development can be seen that the environmental conditions are not well maintained and healthy too. But after the existence of WWTP facilities it can help to dispose of liquid waste from batik so that the environment becomes healthy. The existence of this program is considered sufficient to help to live healthier.

\subsection{Equity}

Equity oriented policy is a policy that can be known as a result or effort is directly distributed. A particular program might be effective, efficient, and sufficient if the cost-benefit is evenly distributed. Funding that is distributed evenly to the community groups must be in accordance with the budget that has been provided so that eventually the community can feel the benefits together. The key to equity is justice or fairness. So that the WWTP program has run well, but in terms of cost it is sufficient but more costs are needed so that batik craftsman in Laweyan Batik Village can benefit from the WWTP facilities so that participation from the Surakarta City Government is required to participate in running this program.

\subsection{Responsiveness}

Responsiveness is a public policy that can be interpreted as a response to public policy objectives for the application of a policy. A policy success can be seen through the response of the community who responded to implementation. Therefore, in advance predicting whether or not the influence will occur if a policy will be implemented, as well as community responses after the impact of a policy has begun to be felt in a positive form of support or in the form of a negative form of rejection. Regarding the community response about before and after this program, it certainly reaped the pros and cons of the community. There are those who accept this program and some who do not accept it but as time goes by it is seen that there are many who use WWTP facilities but also there are still residents who do not want to be connected with batik waste disposal connections to WWTP facilities. This is due to the lack of public knowledge about the disposal of batik waste itself. 


\subsection{Accuracy}

Accuracy refers to the value or price of program objectives and to the strong assumptions that underlie these goals. In fact, if a policy or program has been implemented, the results can be seen whether the objectives set according to initial planning. The accuracy shows that the WWTP Program is only intended for batik craftsman who are willing to participate in the program and make the environment clean and healthy. If it is related to the objectives of the existing WWTP program that is able to motivate the community, as well as the expected target can be achieved in order to realize sustainable development.

\section{CONCLUSIONS}

Policy Evaluation of the WWTP (Waste Water Treatment Plant) Program in Laweyan Batik Village, Surakarta in order establishing sustainable development as follows:

Indicators of effectiveness with the presence of WWTP facilities do not dispose of batik waste any more carelessly. In addition, people will become healthier and cleaner lives. So, we need the support or contribution from the Surakarta City government to be more concerned in overcoming the problem of batik waste.

The efficiency indicator can be seen that the WWTP program is running quite well except that in terms of costs after the preparation of WWTP there are additional costs in the form of costs for maintenance. So that the community objected to being charged for the WWTP with care and maintenance.

Indicators of adequacy can be seen that environmental conditions are not well maintained and healthy. However, after the presence of WWTP facilities can more or less help dispose of batik waste so that the environment becomes clean and healthy. The existence of this program is considered sufficient to help a healthier and cleaner lives.

Indicators of equity can be known by the presence of WWTP and the benefits obtained in the management of batik waste water.

The responsiveness indicator shows that there are those who accept this program and some who do not. However, as time went on, the WWTP facilities were used, but there were still some residents who did not receive to be connected to the batik waste disposal connection to the WWTP facility. This is due to the lack of public knowledge about the disposal of batik waste itself.

The accuracy indicator can be seen that the WWTP Program is only intended for batik craftsman who are willing to join the program and make the environment clean and healthy. If it is associated with the objectives of the existing WWTP program that is able to motivate the community, and achieve targets in order to realize sustainable development.

\section{REFERENCES}

[1] R. B. Arsalan Yousefloo, "Designing an Integrated Municipal Solid Waste Management Network: A case study," Journal of Cleaner Production, 2019.

[2] R. \&. J. P. Chandler, The Public Administration Dictionary, CA: ABC-CLIO: Second Edition: Santa Barbara, 1988. 
[3] M.-Q. W. C. L. Dan Li, "The waste treatment and recycling efficiency of industrial waste processing based on two-stage data envelopment analysis DEA with undesirable inputs," Journal of Cleaner Production, vol. 242, 2020.

[4] W. Dunn, Public Policy Analysis: An Introduction, Englewood Cliffs, NJ: Prentice Hall Inc, 1994.

[5] D. J. T. Krista L. Thyberg, "Drivers of food waste and their implications for sustainable policy development," Resources, Conservation and Recycling, vol. 106, pp. 110-123, 2016.

[6] M. H. M. B. Miles, Analisis Data Kualitatif, Jakarta: UI Press, 2014.

[7] K. Z.-R. María Margallo, "Enhancing waste management strategies in Latin America under a holistic environmental assessment perspective: A review for policy support," Science of the Total Environment, vol. 689, pp. 1255-1275, 2019.

[8] L. Moleong, Metodologi Penelitian Kualitatif, Bandung: Remaja Rosdakarya, 2009.

[9] L. E. Nabaprabhat Paul, "Predicting future water supply-demand gap with a new reservoir, desalination plant and waste water reuse by water evaluation and planning model for Chennai megacity, India," Groundwater for Sustainable Development, vol. 7, pp. 8-19, 2018

[10] Y.-Y. K. Namil Um, "Strategic environmental assessment for effective waste management in Korea: A review of the new policy framework," Waste Management, vol. 82, pp. 129-138, 2018.

[11] W. Parsons, Public Policy: Pengantar Teori dan Praktik Analisis Kebijakan, 2008.

[12] H. Pasolong, Teori Administrasi Publik, 2010.

[13] J. S. Shahriar Shamsa, "Sustainable waste management policy in Bangladesh for reduction of greenhouse gases," Sustainable Cities and Society, vol. 33, pp. 18-26, 2017.

[14] A. Subarsono, Analisis Kebijakan Publik: Konsep, Teori dan Aplikasi, Yogyakarta: Pustaka Pelajar, 2005.

[15] G. F. Taís de S. Pereiraa, "Evaluation of solid waste management sustainability of a coastal municipality from northeastern Brazil," Ocean and Coastal Management, vol. 179, 2019.

Regional Regulation No. 2 of 2006 concerning Environmental Control. 